Hans-Otto Baral and Teppo Rämäa,*

\title{
Morphological update on Calycina marina (Pezizellaceae, Helotiales, Leotiomycetes), a new combination for Laetinaevia marina
}

DOI 10.1515/bot-2015-0049

Received 19 June, 2015; accepted 6 October, 2015; online first 5 November, 2015

Abstract: Laetinaevia marina is a frequent ascomycetous fungus that is widely distributed on the seashores of Scandinavia and Great Britain. It grows on fronds of Fucales (Phaeophyceae) that are washed ashore and lie decaying at the high tide mark or further up on the beach. It is one of the few described marine discomycetes. In the current generic concept it is regarded as a member of Naevioideae (Dermateaceae or Mollisiaceae), while it has previously been placed in the genus Orbilia (Orbiliaceae). We studied fresh collections, in live and dead state, to provide a morphological update on the species and to elucidate its systematic placement using molecular systematics. The hemiamyloid reaction of the apical ring, the absence of croziers, and the faintly refractive vacuolar bodies of the terminal cells of living paraphyses are reported here for the first time. A thin gel sheath surrounding the ascospores was confirmed to exist. Based on morphological characters, ribosomal RNA and protein coding gene sequences published for this species here for the first time, we show that L. marina is distinct from the genera and families it was previously placed in, and propose the new combination Calycina marina, despite its erumpent, sessile, pulvinate and rather immarginate apothecia. Furthermore, we present additional observations on the ecology, phenology, and distribution of the species.

Keywords: algicolous fungi; discomycetous fungi; marine fungi; morphology; phylogeny.

aPresent address: Marbio, UiT - The Arctic University of Norway, Postbox 6050 Langnes, NO-9037 Tromsø, Norway *Corresponding author: Teppo Rämä, Norwegian College of Fishery Science, UiT - The Arctic University of Norway, Postbox 6050 Langnes, Tromsø, NO-9037, Norway, e-mail: teppo.rama@uit.no Hans-Otto Baral: Blaihofstraße 42, 72074 Tübingen, Germany

\section{Introduction}

Discomycetes form a morphological group of filamentous ascomycetes that possess cup-like or discoid fruiting structures (apothecia) in which sexual spores are produced. Among the 424 known marine ascomycetous fungi, there are only nine non-lichenized discomycetous species in the genera Dactylospora Körb., Gloniella Sacc., Lachnum Retz., Laetinaevia Nannf., Patellaria Fr. and Vibrissea Fr. (Suetrong and Jones 2006, Jones et al. 2009, Pang et al. 2014). The number of marine non-lichenized discomycetes is low compared to the number of non-lichenized discomycetes in the terrestrial environment (including freshwater habitats) where these fungi thrive with $>5000$ species estimated (Baral, in Jaklitsch et al. 2015). The low number of marine discomycetes may be due to several reasons, such as sensitivity of the exposed apothecia to grazing marine animals, submersion in saline water and wave action (Suetrong and Jones 2006).

One of these marine discomycetes is Laetinaevia marina (Boyd) Spooner, a microfungus that fruits on decaying seaweed. This is a rather frequent species and found along seashores of Scandinavia and Great Britain. It grows on fronds of the genera Ascophyllum and Fucus (Fucales, Phaeophyceae) which are washed ashore and are degraded by microorganisms. D.A. Boyd made the first collections of L. marina in $\sim 1888$ at West Kilbride (North Ayrshire, Scotland) on Fucus. Based on Boyd's material, Phillips wrote a manuscript that includes the first morphological description of the species (Smith 1909, Kirk and Spooner 1984). In this unpublished manuscript, the species was called “Calloria marina Phil.". Boyd, however, placed the fungus in Orbilia Fr. obviously because of the tiny orange apothecia and paraphyses with clavate heads (Smith 1909). He had also observed the fungus on "Ascophyllum, Halydris \&c. (=etc.)" (Smith 1909) at different sites in the west of Scotland ("Strathclyde") in autumn and spring, and assumed that it occurs throughout the year, wherever decaying seaweed is abundant.

Eriksson (1973) collected the species in April and June to August in 1962-1969 in Denmark (Sjælland), Norway 
(Nordland and Troms) and Sweden (Skåne and Bohuslän) on Ascophyllum nodosum, Fucus serratus and Fucus sp. He retained its systematic placement in Orbilia and concluded that it is widely distributed in Scandinavia. Kirk and Spooner (1984) studied Boyd's preserved Scottish collections, including some collected by W.B. Grove from Wales (Gwynedd) on Ascophyllum nodosum and Fucus vesiculosus in spring and autumn 1907-1919, but did not mention any more recent records. Spooner removed the species from Orbiliaceae and transferred it tentatively to Laetinaevia (Naevioideae, Dermateaceae) based on morphological characters (Kirk and Spooner 1984). Since the type material could not be traced, he designated a lectotype (Arran, Brodick, Invercloy, Ascophyllum nodosum, Apr. 1908, D.A. Boyd) that is preserved in Kew.

The studies above do not include information about morphological characters that can only be observed when living cells are examined. These state-dependent characters include characteristics of the vacuoles of paraphyses, lipid bodies and nuclei in the ascospores, and measurements of turgescent cells. Furthermore, two herbariumstable characters were previously neglected. They concern the type of iodine reaction of the apical ring and the mode of ascus formation at the ascogenous hyphae.

The fungus was also not subjected to phylogenetic analyses based on DNA sequences, and hence the systematic placement and appropriate genus of the species remain unverified. For the present paper, we studied fresh, living collections from Portsmouth, UK, and Central and Northern Norway. Our aims were to provide a morphological revision of the species and study its systematic placement based on DNA extracted from freshly collected material. We have obtained DNA sequences from four gene regions for the first time for this species and describe the ecology, phenology and distribution of the species.

\section{Materials and methods}

\section{Morphological studies and culturing}

Fresh algal thalli with apothecia were studied under a dissecting microscope (Leica MZ16, Leica Microsystems, Wetzlar, Germany). Sections were mounted in tap water. Lugol's solution of high concentration (IKI=1\% $\mathrm{I}_{2}, 3 \% \mathrm{KI}$, $100 \mathrm{ml}$ water) was applied for staining ascus walls, and aqueous Cresyl Blue (CRB) for staining gel and vacuoles. The microscope slides were examined with a Zeiss Standard 14 (Carl Zeiss, Oberkochen, Germany) and Leica DM2500 compound microscope (Leica Microsystems, Wetzlar, Germany). Pictures were taken with Nikon Coolpix
E4500 (Nikon Corporation, Tokyo, Japan), Olympus Colorview I and UC50 microscope cameras (Olympus Soft Imaging Solutions, Münster, Germany). Voucher specimens are preserved in the herbarium of Tromsø University Museum (TROM) and private herbarium of H.B.

One of the voucher specimens, T. Rämä 3180A from Portsmouth (TROM-F26103), was used in culturing of the fungus with the intention of revealing its asexual state. Using sterile techniques, a fragment of fertile hymenium from a single fruiting body was transferred onto a sterile slide containing a drop of distilled water. The suspension was agitated and blown on a malt extract agar plate that was prepared using $4 \mathrm{~g}$ of malt extract agar (Jensen \& Co, Nittedal, Norway) from grocery store in 11 of filtered and autoclaved seawater (0.2SeaMEA). The plate also contained the antibiotic streptomycin $\left(25 \mathrm{mg} \mathrm{l}^{-1}\right)$ (Biochrom AG, Berlin, Germany) and tetracycline (10 $\mathrm{mg} \mathrm{l}^{-1}$ ) (Calbiochem, part of Merck, Darmstadt, Germany). After germination of the spores at $+20^{\circ} \mathrm{C}$ during the first $24 \mathrm{~h}$, the isolate was cultured in the dark at $+5^{\circ} \mathrm{C}$. The fungus grew slowly in culture, and did not produce an asexual state.

\section{Molecular work and phylogenetic analyses}

We extracted DNA of Laetinaevia marina voucher specimens and the culture isolate using a modified cetyltrimethyl ammonium bromide (CTAB) extraction protocol (Murray and Thompson 1980) and amplified the target loci according to Mysterud et al. (2007) and Johnson et al. (2009) with slight modifications. PCR amplifications were performed on a PTC0200 DNA engine (MJ Research, Waltham, MA, USA) and GeneAmp PCR System 9700 (Applied Biosystems, Foster City, CA, USA) using the primer pairs ITS5-ITS4 (White et al. 1990), LROR-LR5 (Vilgalys and Hester 1990, Rehner and Samuels 1994), NS1-NS24 (White et al. 1990, Gargas and Taylor 1992) and RPB1Ac-RPB1Cr (Stiller and Hall 1997, Matheny et al. 2002, both with unpublished modifications by Giho Sung). The primers were used in concentrations of $0.5 \mu \mathrm{M}(0.6 \mu \mathrm{M}$ for RPB1) together with Illustra PuReTaq Ready-To-Go PCR beads (GE Healthcare, Buckinghamshire, UK) in a reaction volume of $25 \mu$. The cyclic PCR program consisted of an initial 3-min denaturation step at $94^{\circ} \mathrm{C}$, followed by 40 cycles of $30 \mathrm{~s}$ at $94^{\circ} \mathrm{C}, 30 \mathrm{~s}$ at $52^{\circ} \mathrm{C}$ (annealing) and $1 \mathrm{~min}$ at $72^{\circ} \mathrm{C}$ (synthesis), and termination with a 10-min elongation step at $72^{\circ} \mathrm{C}$. The PCR products were cleaned using 0.25 units of ExoSAP-IT (Affymetrix, Santa Clara, CA, USA) for $6 \mu \mathrm{l}$ of PCR product.Sequencing reactions were performed on an Applied Biosystems 3130xl Genetic Analyzer (Foster City, CA, USA) in BigDye Terminator sequencing buffer using PCR primers as sequencing primers and the BigDye Cycle Sequencing kit v3.1 (Applied Biosystems, Carlsbad, CA, USA). 
DNA sequences of Calloria urticae (Pers.) J. Schröt. ex Rehm [=C. neglecta (Lib.) B. Hein] and Laetinaevia carneoflavida (Rehm) Nannf. ex B. Hein were provided by Guy Marson (pers. comm., unofficial collaborator at Musée National d'Histoire Naturelle, Paris, France). Crushed apothecia were subjected to direct PCR amplification using the Phire Plant Direct PCR Master Mix kit (F-160 kit, Thermo Scientific, Waltham, MA, USA). Two primers, SF16a and LR17b, were developed (Marson et al., unpublished) to amplify approximately 2500 base pair long sequences of nuclear ribosomal DNA that included the internal transcribed spacer 1 (ITS1), the $5.8 \mathrm{~S}$ gene, the internal transcribed spacer 2 (ITS2), and the $28 \mathrm{~S}$ regions. PCRs were performed in an iCycler (Bio-Rad, Hercules, CA, USA) in a total volume of $20 \mu$ that contained $1 \times$ Phire Plant Direct PCR Master Mix and $0.5 \mu \mathrm{M}$ of each primer. Finally, $1 \mu$ of the fungal DNA from the extraction supernatant was added to the reaction tube. Cycling conditions consisted of an initial denaturation at $98^{\circ} \mathrm{C}$ for $5 \mathrm{~min}$, followed by 40 cycles with denaturation at $98^{\circ} \mathrm{C}$ for $7 \mathrm{~s}$, annealing at $59.9^{\circ} \mathrm{C}$ for $8 \mathrm{~s}$ and $40 \mathrm{~s}$ of elongation at $72^{\circ} \mathrm{C}$, and a final elongation at $72^{\circ}$ for $3 \mathrm{~min}$. PCR products were purified with the Agencourt AMPure XP system (Beckman Coulter, Brea, CA, USA). The whole region was sequenced using seven sequencing reactions that generated partially overlapping fragments. The forward primers used were SF16a, 5.8SR and LR3R, and the reverse primers LR17b , LR5, LR1 and 5.8S (Vilgalys and Hester 1990). Sequencing was performed using the Big Dye Terminator chemistry (Applied Biosystems, Carlsbad, CA, USA) on an ABI 3730 capillary DNA automated sequencer (Applied Biosystems, Carlsbad, CA, USA).

Sequenced forward and reverse strands were assembled and manually checked using Geneious ${ }^{\circledR}$ v. 7.1.7 and v. 7.1.4 (Biomatters Ltd., Auckland, New Zealand). The alignments were made using the G- and E-INS-i algorithm in MAFFT v. 7.0.7 (Katoh and Standley 2013) followed by manual adjustment and removal of ambiguously aligned sites in Geneious. A three-gene dataset was constructed to determine the higher order placement of $L$. marina in the Ascomycota tree of life. It contained SSU, LSU and RPB1 sequences of 27 taxa (Table 1). Long insertions and ambiguously aligned positions were removed from the alignments of individual genes. Preliminary analyses for each gene were run in MrBayes v. 3.2.4 (Ronquist et al. 2012) using the same settings as the final analyses. The resulting gene trees showed no incongruence, hence the alignments were concatenated and the final analyses run in MrBayes. The analysis was run using three partitions (by gene), each with the same model settings that were unlinked across the partitions. Based on results from
jModeltest v. 2.1.6 (Guindon and Gascuel 2003, Darriba et al. 2012), a GTR model with gamma-distributed rate variation across sites and a proportion of invariable sites included was used in combination with Dirichlet distributed substitution rate and state frequency priors. Neolecta irregularis (Peck) Korf et J.K. Rogers (Taphrinomycotina) was used as the outgroup taxon and three subruns, each with four chains, were run for 20 million generations, after which the standard deviation of split frequencies was $<0.01$ and the Markov chain Monte Carlo $(\mathrm{mcmc})$ had reached stationarity as inspected in Tracer $\mathrm{v}$. 1.6 (Rambaut et al. 2014). First 5000 trees of the resulting 20,001 ones were discarded as burnin, and the remaining trees were used to calculate the posterior probability (PP) support values for the nodes of a consensus tree produced using the $50 \%$ majority rule option.

The ITS dataset was set up to examine the systematic placement of $L$. marina within the order Helotiales. It contained sequences belonging to 26 fungal isolates and voucher specimens (Table 1) including the outgroup taxon Mollisia cinerea (Batsch) P. Karst., and had 451 sites of which $216 \mathrm{bp}$ were unique. Two different versions of the ITS analysis were conducted using MrBayes (Ronquist et al. 2012). First, the analysis was run using a GTR model with gamma-distributed rate variation across sites and the same priors as above. In the second version, a TIM2ef $+\mathrm{G}$ substitution model with equal nucleotide frequencies and fixed substitution rates was specified, as suggested by jModeltest (Guindon and Gascuel 2003, Darriba et al. 2012) based on Bayesian information criteria and decision theory performance. Both versions were run and summarized in the same way as the three-gene dataset. Both produced similar consensus trees, with only small differences in posterior probability support values for some of the nodes, and the tree produced with TIM2ef $+\mathrm{G}$ model is shown in the results.

The sequences generated for this study are deposited in GenBank (Benson et al. 2014) under accession numbers KT185666-KT185667 and KT185669-KT185677. All sequences used in this study are listed in Table 1.

\section{Results}

\section{Systematics}

The combined three-gene analysis showed that Laetinaevia marina is related to Calycina citrina (Hedw.) Gray [三 Bisporella citrina (Batsch) Korf et S.E. Carp.] in the Helotiales ( $\mathrm{PP}=1)$, whereas sequences of Orbiliomycetes are distant (Figure 1). The ITS analysis placed L. marina 
Table 1: Species, isolates and GenBank accession numbers of the ascomycete sequences used in the phylogenetic analyses.

\begin{tabular}{|c|c|c|c|c|c|}
\hline \multirow[t]{2}{*}{ Species } & \multirow[t]{2}{*}{ Isolate } & \multicolumn{3}{|c|}{ Three-gene dataset } & \multirow[t]{2}{*}{ ITS dataset } \\
\hline & & SSU & LSU & RPB1 & \\
\hline Ascocoryne sarcoides & Aftol 1834 & FJ176830 & FJ176886 & - & - \\
\hline Brunnipila fuscescens & FC-2197 & - & - & - & AB481254 \\
\hline Brunnipila fuscescens & KUS-F52031 & - & JN086695 & - & - \\
\hline Bulgaria inquinans & Aftol 916 & DQ471008 & DQ470960 & DQ471152 & - \\
\hline Calloria urticae & G.M. 2015-04-12 \#5 & - & - & - & KT185667 \\
\hline Calycellina punctata & Cantrell GA18 & - & - & - & U57494 \\
\hline Calycina citrina ${ }^{\mathrm{a}}$ & F14046 (UBC) & - & - & - & AF335454 \\
\hline C. citrina $a^{\mathrm{a}}$ & Andy $9 / 27 / 03$ & - & AY789385 & - & AY789386 \\
\hline C. citrina ${ }^{\mathrm{a}}$ & Aftol 1301 & FJ176815 & FJ176871 & - & - \\
\hline C. citrina & F118000 & - & - & - & KC412005 \\
\hline C. claroflava & F132983 & - & - & - & KC412006 \\
\hline C. herbarum & KUS-F52362 & - & - & - & JN033407 \\
\hline C. herbarum & KUS-F51458 & - & - & - & JN033390 \\
\hline C. lactea & H.B. 7224 & - & - & - & KC412007 \\
\hline C. languida & F116600 & - & - & - & KC412003 \\
\hline C. languida & F116599 & - & - & - & KC412002 \\
\hline C. marina & TROM-F26093 & KT185672 & KT185670 & - & KT185677 \\
\hline C. marina & TROM-F26098 & - & - & - & KT185676 \\
\hline C. marina & TROM-F26101 & KT185673 & KT185671 & KT185669 & KT185674 \\
\hline C. marina & TROM-F26103 & - & - & - & KT185675 \\
\hline C. populina ${ }^{\mathrm{b}}$ & CBS 247.62 & - & - & - & JN033382 \\
\hline Capronia munkii & Aftol 656 & EF413603 & EF413604 & EF413605 & - \\
\hline C. pilosella & Aftol 657 & DQ823106 & DQ823099 & DQ840554 & - \\
\hline Chalara dualis & ICMP 14950 & - & - & - & EF029209 \\
\hline C. pseudoaffinis & CCF 3979 & - & - & - & FR667224 \\
\hline Chloroscypha enterochroma & Aftol 67 & AY544700 & AY544656 & - & - \\
\hline Cladonia stipitata & Aftol 1657 & DQ973003 & DQ973026 & DQ973050 & - \\
\hline Debaryomyces hansenii & JCM 1990 & JN940470 & JN940504 & JN992543 & - \\
\hline Dermea acerina & Aftol 941 & DQ247809 & DQ247801 & DQ471164 & - \\
\hline Heyderia abietis & HMAS71954 & AY789295 & AY789296 & - & - \\
\hline Hyalopeziza pygmaea & KUS-F51564 & - & JN086713 & - & JN033410 \\
\hline Hymenoscyphus fructigenus & M159 & EU940081 & EU940157 & - & - \\
\hline Hyphodiscus hymeniophilus & TNS-F31802 & - & AB546950 & - & AB546951 \\
\hline Laetinaevia carneoflavida & G.M. 2014-07-25 & - & - & - & KT185666 \\
\hline Mollisia cinerea & CBS 128349 & - & - & - & JF514855 \\
\hline M. cinerea & Aftol 76 & DQ470990 & DQ470942 & DQ471122 & - \\
\hline Mollisina uncinata & TNS-F38901 & - & JN086757 & - & JN033457 \\
\hline Naevala perexigua & CBS 115920 & - & - & - & AY853229 \\
\hline Neofabraea malicorticis & Aftol 149 & AY544706 & AY544662 & DQ471124 & - \\
\hline Neolecta irregularis & Aftol 1363 & DQ842040 & DQ470986 & - & - \\
\hline Orbilia auricolor & Aftol 906 & DQ471001 & DQ470953 & - & - \\
\hline O. vinosa & Aftol 905 & DQ471000 & DQ470952 & DQ471145 & - \\
\hline Peziza vesiculosa & Aftol 507 & DQ470995 & DQ470948 & DQ471140 & - \\
\hline Phialina lachnobrachyoides & KUS-F52576 & - & - & - & JN033424 \\
\hline Pilidium acerinum & BPI 843554 & AY487090 & AY487089 & - & - \\
\hline Sclerotinia sclerotiorum & Aftol 928 & DQ471013 & DQ470965 & - & - \\
\hline Trichoglossum hirsutum & Aftol 64 & AY544697 & AY544653 & DQ471119 & - \\
\hline
\end{tabular}

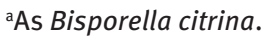

${ }^{\mathrm{b}}$ As Calycellina populina.

'As Naevala minutissima.

The sequences generated for this study are in bold face. 


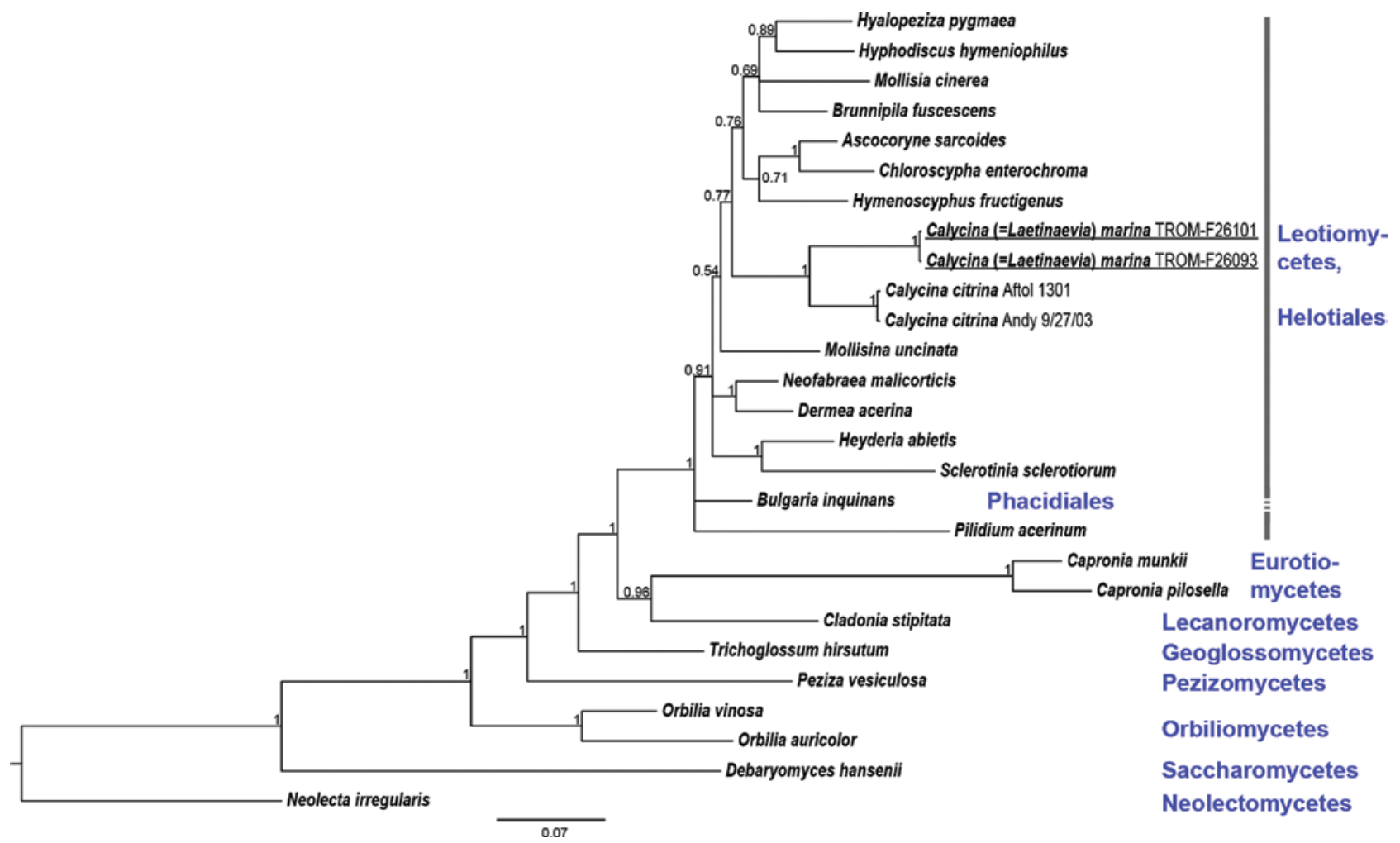

Figure 1: Fifty percent majority rule consensus tree from the combined three-gene analysis (SSU, LSU, RPB1) showing the placement of Calycina marina within the phylum Ascomycota. The log-likelihood of the tree was $\ln (\mathrm{L})=-16,075.01$. Node support is given as posterior probabilities at the nodes, the scale bar shows estimated substitutions per site, and strain or isolate identifiers follow taxon names. The new sequences generated for this study are underlined.

sequences closest to Calycina claroflava (Grev.) Kuntze (Figure 2, PP=0.96). This result was also obtained in several preliminary runs using slightly different sets of taxa and run options (results not shown). Calycina herbarum (Pers.) Gray (type of Calycina Nees ex Gray) forms a sister taxon to this clade $(\mathrm{PP}=0.99)$ which contains also Calycina populina (Fuckel) Kuntze and Calycina lactea (Sacc.) Baral et al. Together with further species placed in Calycina, and with those assigned to the genera Mollisina Höhn. ex Weese, Phialina Höhn., and Calycellina Höhn., this group of fungi represents the family Pezizellaceae $(\mathrm{PP}=0.99)$ as recently resurrected by Baral (in Jaklitsch et al. 2015).

Three Naevioideae species, Calloria urticae, Laetinaevia carneoflavida, and Naevala perexigua (Roberge ex Desm.) K. et L. Holm [=Naevala minutissima (Auersw.) B. Hein], were placed basal to Pezizellaceae in our analysis (Figure 2). Taxa that were found by us to show morphological similarities with L. marina, i.e. Cyathicula De Not. (Helotiaceae) in the apical ring type and Corticifraga D. Hawksw. et R. Sant. (incertae sedis) in excipular characters, were not closely related with it due to high genetic distance between aligned sequences (results not shown).

\section{Taxonomy}

Calycina marina (Boyd) Rämä et Baral, comb. nov. (Figures 3 and 4) MB812843

Basionym: Orbilia marina Boyd, in Smith, Trans. Br. Mycol. Soc. 3: 113, pl. 6 fig. 1 (1909) [1908], as "Orbilia marina (Phil.) Boyd"

[ $\equiv$ Orbilia marina (W. Phillips) Boyd, in Elliott et al. (ed.), Fauna, Flora \& Geology of the Clyde Area: 69 (1901) nom. nud. Art. 38.1(a)]

$\equiv$ Laetinaevia marina (Boyd) Spooner, in Kirk and Spooner, Kew Bull. 38: 568 (1984)

Typification: Holotype: unknown. Lectotype: K(M) 33419.

Explanation of symbols: ${ }^{*}=$ microscopic characters of living cells, $\dagger=$ microscopic characters of dead cells, numbers in \{\} refer to the number of collections, in which a specific character was observed.

Apothecia moist or rehydrated $0.25-0.65 \mathrm{~mm}$ diam., 0.13-0.16 mm thick (receptacle 0.09-0.11 mm), pulvinate, 


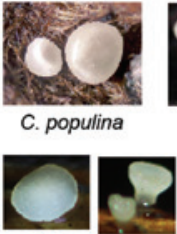

C. languida
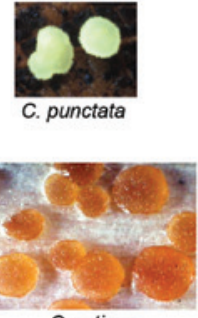

C. urticae

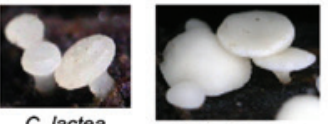
C. herbarum

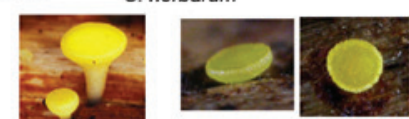

C. claroflava
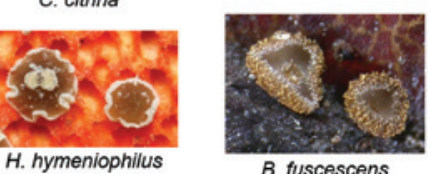

B. fuscescens

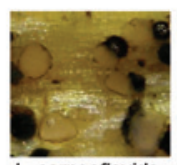

L. carneoflavida

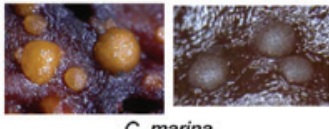

C. marina
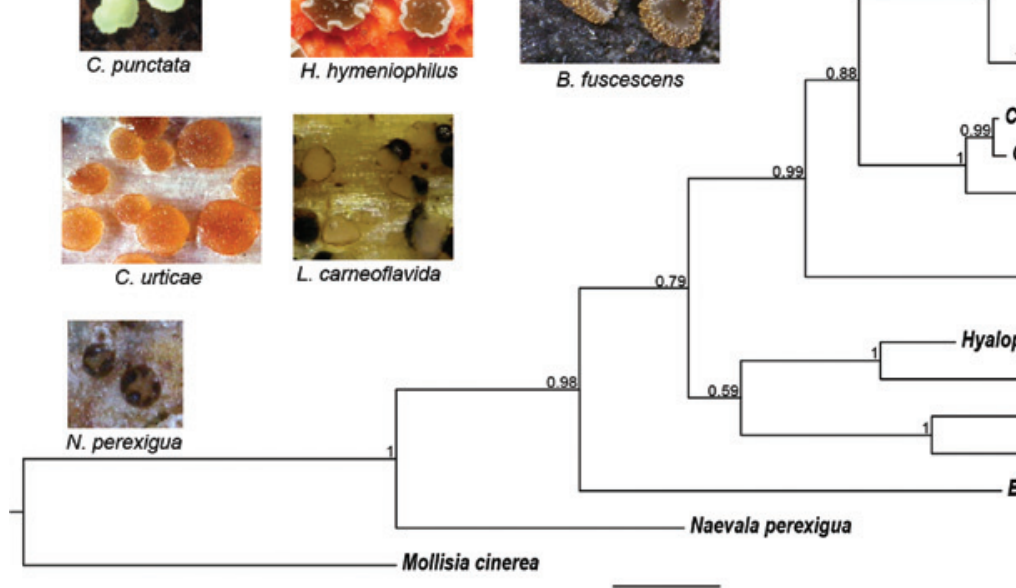

Calycina languida F116600

Calycina citrina F118000

0.22 Calycina citrina F14046

- Calycina citrina Andy 9/27/03

Mollisina uncinata

- Phialina lachnobrachyoides

Calycellina punctata

Hyaloscyphaceae

Naevioideae

Lachnaceae

Naevioideae

Figure 2: Fifty percent majority rule consensus tree from the Bayesian ITS analysis showing placement of $C$. marina within the Pezizellaceae (Helotiales) and its relationship to members of Naevioideae (Nannfeldt 1932). The log-likelihood of the tree was ln(L)=-2912.00. Node support is given as posterior probabilities at the nodes, the scale bar shows estimated substitutions per site and strain or isolate identifiers follow taxon names. The new sequences generated for this study are underlined. Clade annotations in coloured font are based on Nannfeldt (1932) and Hein (1976). Origin of photos: Brunnipila fuscescens: H.O.B. (H.B. 8156a), Calycina citrina: P. Thompson, C. claroflava: H.O.B. (H.B. 7666), C. herbarum: H.O.B. (H.B. 8947), C. lactea: H.O.B. (H.B. 9861), C. languida: B. Perić (XII.2014), C. marina: H.O.B. (H.B. 5792) and T.R. (T.R. 3160B), C. populina: E. Rubio (ERD-6306), Calycellina punctata: P. Thompson (19.X.2009), Hyphodiscus hymeniophilus: S. Blaser (XI.2014), Laetinaevia carneoflavida: G. Marson (G.M. 2014-07-25), Naevala perexigua: H.O.B. (H.B. 9308a).

slightly to strongly translucent, round, slightly gelatinous, scattered or often subgregarious to gregarious; disc whitish cream, light to bright yellowish-orange-ochraceous, or pale to dark greyish-brownish-alutaceous, flat at first, soon slightly to strongly convex, margin eventually indistinct, not protruding, smooth; sessile, erumpent from beneath cortex of thallus; dry flat to medium convex, \pm concolorous. Asci * (50-) $58-87(-96) \times(6.5-) 7-8.5(-9.7) \mu \mathrm{m}\{3\}$, $+(38-) 43-60(-76) \times(5.5-) 6-7.5(-8) \mu \mathrm{m}\{3\}$, (4-)8-spored, spores *obliquely biseriate ( $\dagger$ uniseriate below), pars sporifera * (26-)30-40(-55) $\mu \mathrm{m}$ long $\{3\}$, living mature asci protruding up to $15-20 \mu \mathrm{m}$ beyond paraphyses but some also $\sim 10 \mu \mathrm{m}$ shorter than those, $+5-10 \mu \mathrm{m}$ shorter than paraphyses; apex $(* / \dagger)$ slightly conical, apical ring $(\dagger)$ staining medium to strongly dirty blue in IKI at low concentration, at high concentration dirty red-brown (hemiamyloid, type $\mathrm{RB})\{3\}$, immature $1.7 \times 1.1 \mu \mathrm{m}$ (height $\times$ width), becoming $1.2 \times 1.5 \mu \mathrm{m}$ when mature, protruding into ascoplasm by forming a small apical chamber, distally not extending up to ectotunica, Conchatium-type, deeply pure blue in IKI when $\mathrm{KOH}$-pretreated $\{1\}$, contracted to $0.5-0.8 \times 1-1.4 \mu \mathrm{m}$, immature with thick lateral wall (Figure $4 \mathrm{w}$ lower left); base narrowed, arising from simple septa without basal protuberances $\{5\}$; entire wall surface slightly to distinctly lilac in CRB, especially towards apex. Ascospores *(7-)813(-15) $\times(2.8-) 3.3-4(-4.5) \mu \mathrm{m}\{4\}$, exceptionally * $4-5.5 \mu \mathrm{m}$ wide $\{1\},+(5.5-) 7-11(-12.5) \times(2.5-) 2.8-3.3 \mu \mathrm{m}\{2\}$, subcylindrical to subfusoid or ellipsoid, homopolar or only very slightly heteropolar, ends obtuse, straight to slightly inequilateral; containing 1-3 lipid bodies $0.3-0.5(-1) \mu \mathrm{m}$ diam. in each half or near the ends, lipid content $0.5-1$, uninucleate (seen in living spores in IKI), lacking glycogen; wall \pm negative in CRB, sometimes with sheath; overmature spores 1-septate, up to $16 \mu \mathrm{m}$ long. Paraphyses apically slightly to rather strongly clavate-capitate, rarely ellipsoid-fusoid or moniliform-lageniform, hyaline; terminal cell *(7-)8-17(-21)×(3-)3.5-6(-8.3) $\mu \mathrm{m}\{3\}$, +(3-)4$5,3 \mu \mathrm{m}$ wide $\{1\}$, covered by a very faintly refractive, thick, hyaline gel staining deep lilac in CRB; terminal cell (*) containing \pm large and globose, faintly refractive, hyaline 


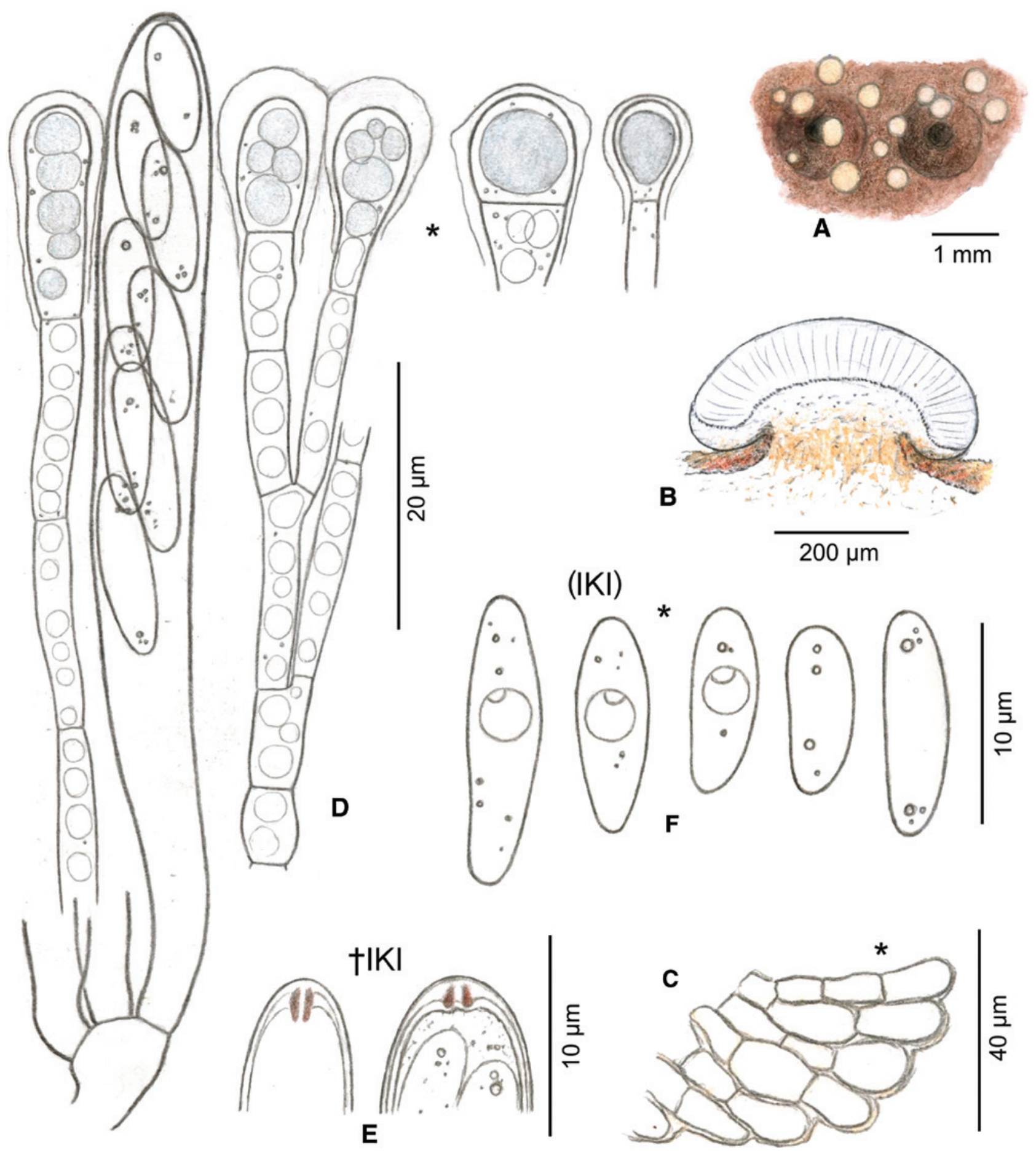

Figure 3: Calycina marina (H.B. 5792). (A) A swarm of apothecia on thallus of Fucus serratus (with conceptacles and their ostiole openings); (B) Median section of apothecium; (C) Median section of ectal excipulum near margin; (D) Ascus and paraphyses; (E) Ascus apices (immature and mature), with hemiamyloid (dirty red) apical rings; (F) Ascospores (three left with central nucleus and nucleolus visible when adding IKI). All elements in living state, except for (E).

vacuolar bodies that stain deep (blackish) red-brown in IKI and pale turquoise in CRB $\{1\}$ (but not seen in other collections), (†) with many minute, light orange drops (in $\mathrm{H}_{2} \mathrm{O}$ ); lower cells *9-18×1.8-3(-4) $\mu \mathrm{m}\{3\}$, with non-refractive vacuoles; branched at base, rarely at uppermost septum or even near apex. Medullary excipulum pale to light yellow-ochre, $\sim 30-50 \mu \mathrm{m}$ thick, of slightly gelatinized, more or less irregularly oriented, dense textura angularisprismatica, indistinctly delimited from ectal excipulum, basal part deep orange-ochre, emerging from inner parts 


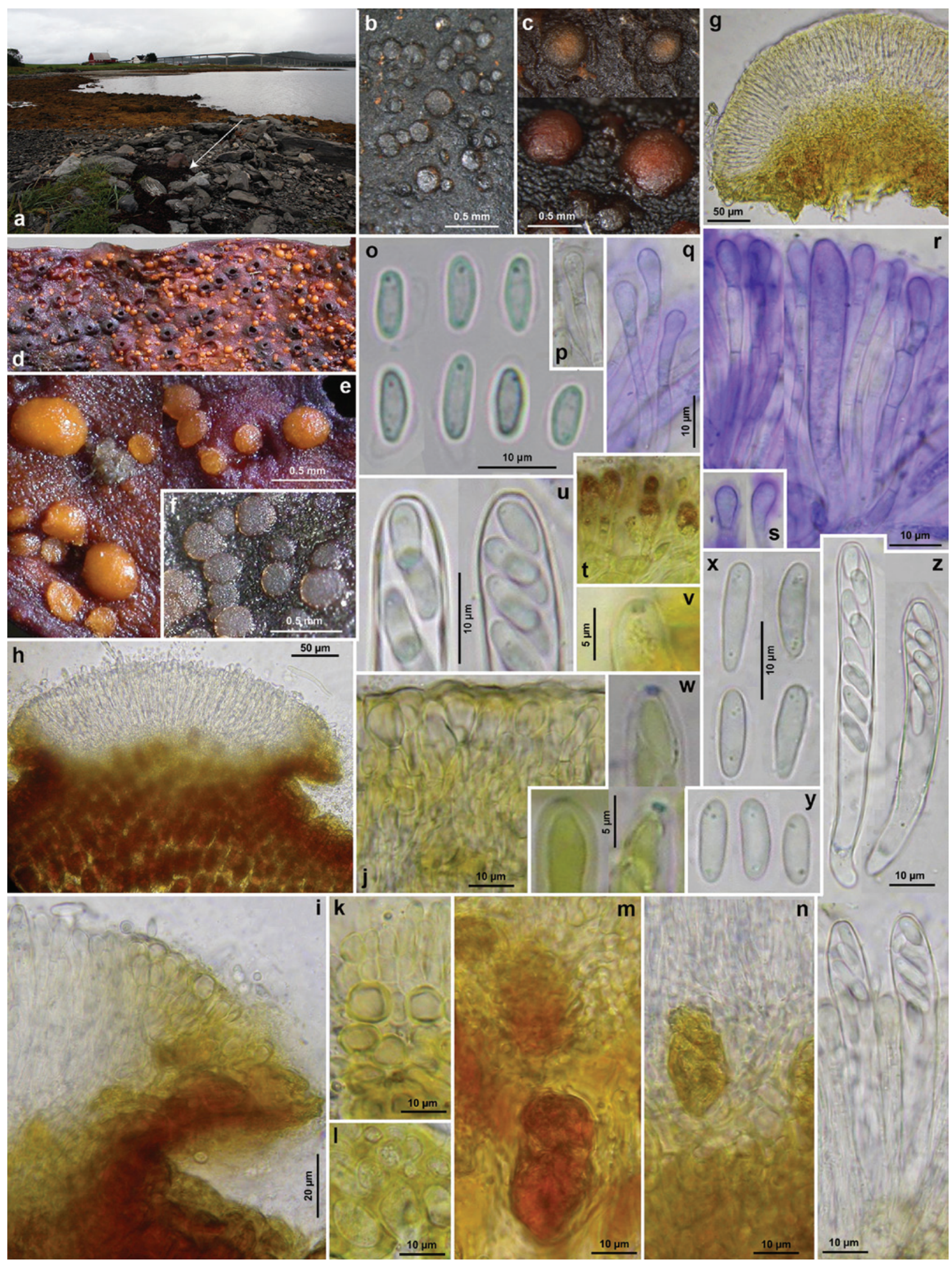


Figure 4: Calycina marina (a) Habitat of T.R. 3166 on Ascophyllum nodosum, the exact locality is marked with an arrow. (b) Dry apothecia. (c-f) Rehydrated apothecia. (g-h) Median sections through apothecia in $5-10 \% \mathrm{KOH}(\mathrm{g})$ and $\mathrm{H}_{2} \mathrm{O}(\mathrm{h})$. (i) Enlargement of (h), showing marginal excipulum in $\mathrm{H}_{2} \mathrm{O}$. (j-l) Marginal excipulum in internal view in squash mount in $\mathrm{H}_{2} \mathrm{O}$ (j) and in external view showing thick-walled (gelatinized) cells of ectal excipulum in $\mathrm{KOH}$ $(\mathrm{k}-\mathrm{l})$. (m) Median section of basal part of ectal excipulum, enclosing host tissue in $\mathrm{H}_{2} \mathrm{O}$. (n) Central part of medullary excipulum in $\mathrm{H}_{2} \mathrm{O}$. $(0, x-y)$ Ascospores in $\mathrm{H}_{2} \mathrm{O}$. (p-t) Paraphyses in $\mathrm{H}_{2} \mathrm{O}(p), \mathrm{CRB}(\mathrm{q}-\mathrm{s})$ and IKI (t). (u) Apices of mature asci in $\mathrm{H}_{2} \mathrm{O}$. (v) Apex of immature ascus in IKI. (w) Apices of immature and mature asci in $\mathrm{KOH}+\mathrm{IKI}$. (z) Mature asci in $\mathrm{H}_{2} \mathrm{O}$. All microscopic photos (except $\mathrm{g}, \mathrm{k}-\mathrm{l}, \mathrm{v}-\mathrm{w}$ ) in living state; $d$-e were taken in May 2015, 18 years after being collected. Specimens examined: a, f, h-j, m-n, t-v, x, z: T.R. 3166 (H.B. 9909); b, o: T.R. 3173; c: T.R. 3192 (above) and T.R. 3193, d-e, g, k-l: H.B. 5792; p-s, y: T.R. 3167 (H.B. 9910); w: UME 25785 (H.B. 9953).

of thallus by an upwards oriented, strongly gelatinized textura intricata-porrecta. Ectal excipulum light to bright yellow-ochre near base, of \pm strongly gelatinized textura prismatica-globulosa oriented at a $30-45^{\circ}$ angle to the surface from base to margin, $\sim 20-50 \mu \mathrm{m}$ thick at base and lower flanks, cells * $8-17 \times 3-11 \mu \mathrm{m}\{2\} ; 30-50 \mu \mathrm{m}$ thick near margin, subhyaline to light yellow, slightly gelatinized, marginal cortical cells "7.5-13.5(-16)×4.5-8(-11) $\mu \mathrm{m}\{2\}$; gel slightly to medium refractive, covering also cortical cells; cells containing a few minute lipid bodies; crystals absent. Anchoring hyphae in thallus rather abundant, hyaline to pale yellow, undulating, $\uparrow 2-3.5 \mu \mathrm{m}$ wide, walls $0.2-0.5(-1) \mu \mathrm{m}$ thick $\{1\}$. Asexual state: unknown. Cultural characteristics: Colonies on 0.2SeaMEA slow growing, $11 \mathrm{~mm}$ in diam. after 3 months of growth at $5^{\circ} \mathrm{C}$ in dark, margin filiform, white to creamish white; mycelium on agar surface and immersed, vegetative hyphae 2.5-4.0 $\mu \mathrm{m}$ wide; no conidiophores or conidia observed.

Habitat: At high tide mark and in the splash zone, on lower and upper face of stranded, decaying thalli of Ascophyllum nodosum $\{8\}$, Fucus serratus $\{1\}$, F. vesiculosus $\{3\}$ lying on sea shore. Assoc.: sclerotia of a Typhula (hyaline to ochraceous, sterile, spherical bodies $0.25-0.4 \mathrm{~mm}$ diam.). Desiccation tolerance: after 3 days in herbarium many \pm immature asci and lower cells of paraphyses still viable. Phenology: Year-round (see also Eriksson 1973, Kirk and Spooner 1984).

Specimens examined: England, Hampshire, Portsmouth, Eastney, entrance to Portsmouth Harbor, on decaying Ascophyllum nodosum above or at high tide mark, 23.I.2015, T. Rämä 3180A (TROM-F26103), 3181 (TROMF26105), 3182 (TROM-F26106); Scotland, Aberdeenshire,
Catterline Bay, Catterline pier, on decaying A. nodosum above high tide mark, 4.VI.2015, T. Rämä 3195 (TROMF26122); Norway, Sør-Trøndelag, $9 \mathrm{~km}$ WNW of Trondheim, 1 km E of Flakk, on thallus of Fucus serratus, 3.V.1997, O. Eriksson (H.B. 5792); Nordland, Nesna, on decaying $A$. nodosum, VIII.1968, O.E. Eriksson 3850 (UME 25785, H.B. 9953); Troms, Håkøya, Haugåsstrand, on decaying $A$. nodosum in splash zone, 21.VI.2014, T. Rämä 3160B (TROMF26101); at high tide mark, 5.V.2015 T. Rämä 3192 (TROMF26112); T. Rämä 3193 (TROM-F26113); N shore near Vika, on decaying $F$. vesiculosus at high tide mark after spring tide, 19.VIII.2014, T. Rämä 3170 (H.B. 9908); T. Rämä 3171 (H.B. 9910); Kvaløya, Finnland, on decaying A. nodosum at high tide mark after spring tide, 16.VIII.2014, T. Rämä 3166 (H.B. 9909); T. Rämä 3167; same site, on decaying $A$. nodosum at high tide mark after spring tide, 8.IX.2014, T. Rämä 3172 (TROM-F26092), 3173 (TROM-F26098); Nordfjordbotn, on decaying A. nodosum in splash zone, 20.VI.2013, T. Rämä 3149A (TROM-F26093, TROM-F26094) and E.B.G Jones; Troms $\emptyset$, Tromsøya, Lanes, on decaying A. nodosum in splash zone, 9.VI.2011, T. Rämä 3142 (TROM-F26095); Tromsø University Museum, on decaying A. nodosum in splash zone, 26.II.2015, T. Rämä 3190 (TROM-F26091).

\section{Discussion}

\section{Morphology}

The results of our morphological studies on Calycina marina agree largely with the original description of Orbilia marina and further amendments to it provided by Eriksson (1973) and Kirk and Spooner (1984). The original description by Phillips includes apothecia $0.25 \mathrm{~mm}$ diam., "scattered, erumpent, sessile, at first concave, then plane or convex, thin, transparent when moist, circular, varying from alutaceous to pale orange". The "elliptic-oblong" spores are given as rather short and wide $(8-10 \times 4 \mu \mathrm{m})$ compared to the present data, but the provided illustration shows variation in spore width, suggesting that $3 \mu \mathrm{m}$ wide spores also occurred. Eriksson (1973) discovered the species in Scandinavia, confirmed Boyd's description and amended it by apothecia up to $0.4 \mathrm{~mm}$ diam. (dry), growing in swarms, their basal parts composed of scleroplectenchymatous hyphae, branched paraphyses with swollen heads imbedded in gelatinous sheaths, asci with an apical ring though not clearly positive in iodine, and ascospores surrounded by a thin gelatinous sheath.

In the lack of American records, Kohlmeyer and Kohlmeyer (1979) examined authentic material in Herb. K. 
The authors mainly repeated Eriksson's description and added a spore size of $7.5-10 \times 4-5 \mu \mathrm{m}$ and, like Eriksson, they thought that the ascus apical rings were inamyloid. This negative result is probably a methodological one: they used Melzer's reagent without KOH-pretreatment, which suppresses hemiamyloid reactions (see Baral 1987, 2009).

Spooner (in Kirk and Spooner 1984) described the apical ring as "rather shallow, outlined blue in Melzer's reagent", and the spores as 9-11(-13) $\times 2.5-3.5 \mu \mathrm{m}$, "narrowly ellipsoid, often slightly clavate, inequilateral, with 2 small polar guttules, occasionally developing a median septum". The ectal excipulum is said to be formed of subhyaline to very pale brown subangular cells at the base $(4-7 \times 2-3.5 \mu \mathrm{m})$, with slightly thickened, refractive walls, $10-12 \mu \mathrm{m}$ thick at the flanks, here of parallel, $2 \mu \mathrm{m}$ wide hyphae, at the margin with broader, clavate cells of 8-12×4-7 $\mu \mathrm{m}$.

In our study, we observed even larger apothecia, up to $0.5-0.65 \mathrm{~mm}$ in diameter when moist, and a clear iodine reaction in the ascus apex in contrast to Eriksson (1973) and Kohlmeyer and Kohlmeyer (1979). We find a spore shape that agrees well with Eriksson (1973) and Kirk and Spooner (1984), being straight or slightly inequilateral, partly fusoid and with obtuse ends. A median septum, as reported by Kirk and Spooner (1984), was occasionally seen by us in overmature spores, but never inside living asci. According to Eriksson's (1973) and our observation, a gelatinous sheath surrounds the ascospores (Figure 4). However, this sheath was not seen in every collection studied by us, and might be more difficult to demonstrate in herbarium material.

A rather large variation in ascus and spore dimensions was noted among our collections. Ascus length and width did not even overlap when comparing measurements from some of the living specimens. Extraordinarily wide spores of $8-10 \times 4-5.5 \mu \mathrm{m}$ were seen in some apothecia of T.R. 3170 (H.B. 9908), while other apothecia of the same sample showed the typical narrow spores of (7-)8-11(-12) ×3.2-4.2(-4.5) $\mu \mathrm{m}$. Another collection (T.R. 3166, H.B. 9909) contained rather long spores of (8-)10$13(-15) \times 3.3-4.3 \mu \mathrm{m}$. Two further measurements underline this variation: $(7-) 9-13(-14) \times(2.8-) 3.2-3.8 \mu \mathrm{m}$ in the sample from which the drawing is derived (H.B. 5792), and 9-12×3.5-4 $\mu \mathrm{m}$ in T.R. 3171 (H.B. 9910). A rather large variation was also noted in paraphysis width, both at the apex and in its lower parts.

\section{Generic placement}

Laetinaevia marina is here transferred to Calycina mainly based on the molecular data. Macroscopically it shows, however, little similarity with members of that genus as it deviates in erumpent, sessile, cushion-like, alutaceous to light ochre-orange pigmented apothecia, though the colour varies considerably among populations and includes also whitish-cream when fresh. Due to their translucence in the hydrated state, the apothecia may take on the dark color of the host tissue beneath. In ascus characters, a certain morphological similarity exists with Calycina, particularly the apical ring, though this structure is more reminiscent of the Conchatium-type. However, paraphyses with short-celled, inflated terminal cells with gel caps are unknown in Calycina, and short, hair-like cells on the ectal excipulum, typical of that genus, were not observed here. Drought tolerance is a further feature that was not observed in species of Calycina, and obviously originates from the harsh environment at the seashore.

Spooner (in Kirk and Spooner 1984) removed this discomycete from Orbiliaceae because of the excipular structure, erumpent apothecia, amyloid apical rings, and eventually septate spores. However, Spooner was unaware that some of these features do indeed occur in that family (excipulum of elongate prismatic cells, erumpent apothecia, septate spores). Instead, he saw a relationship with the Naevioideae, at that time a subfamily of Dermateaceae, and tentatively transferred the species to Laetinaevia, mainly because of the clavate marginal cells. Spooner also compared the genera Calloria Fr., in which the species was originally placed by W. Phillips, and Gloeopeziza Zukal.

Our results do not corroborate a placement in Laetinaevia. The ascus apex resembles more that of Cyathicula cyathoidea (Bull.) Thüm. (Conchatium-type, Figures 3E, 4v; Triebel and Baral 1996, Figure 5), whereas typical Laetinaevia species have a "T-shaped" ring of the Pezicula-type. The apical cell of each paraphysis contains a few large, globose, slightly refractive vacuolar bodies (Figure 3D) which stain pale turquoise in CRB and deep blackish red-brown in IKI, features so far not seen in personally studied Laetinaevia species but typical of Calycina species. However, these vacuolar bodies could not be seen in Ascophyllum samples when mounted in water or CRB (Figures $4 \mathrm{p}-\mathrm{s}$ ), although a distinct red-brown reaction of the vacuoles in IKI was noted (Figure 4t). Concerning the earlier placement in Orbilia, nothing conforms with a relationship with the Orbiliomycetes, apart from the ascus wall surface that stains lilac in CRB (Figure 4r). The amyloid ring is the main argument against such placement, and also a spore body, typical of Orbilia, is absent from the living spores.

Sequences are largely lacking for taxa placed in the Naevioideae. However, our phylogenetic analyses demonstrate $C$. marina as being related, yet distant, to the only three fungi of the Naevioideae as defined by Nannfeldt 
(1932) and Hein (1976) for which ITS sequences were available, and for which the family name Calloriaceae could be applied: Calloria urticae, Laetinaevia carneoflavida, and Naevala perexigua. It was a surprise for us that C. marina turned out to be phylogenetically closely associated with species of Calycina and their Chalara asexual states, instead of Corticifraga which is morphologically more similar. The phylogenetic analysis based on the ITS barcoding region (Schoch et al. 2012) placed it close to the type of Calycina, C. herbarum. However, we could not resolve the relationships between the studied Calycina species and the Chalara anamorphs present in GenBank due to some unsupported nodes.

Based on our results, the name Calycina populina should be used instead of Calycellina populina (Fuckel) Höhn., since the type species Calycellina punctata (Fr.) Lowen et Dumont is placed in a separate clade with $\mathrm{Mol}$ lisina uncinata Arendh. et R. Sharma and Phialina lachnobrachyoides (Raitv.) Huhtinen. There are many Calycina species on herbaceous, foliose or woody substrates that remain to be sequenced, and hence, can change our view on the systematics of this genus.

In the anticipation of future molecular work based on freshly collected and documented material, we place this marine discomycete in Calycina, to which it is molecularly closely affiliated.

\section{Ecology}

Calycina marina is the only species now recognized in Calycina that grows on seaweed. It can be found on brown seaweed but has clearly been overlooked, due to its unexpected habitat and the paucity of mycologists recognising it. This fungus can be detected on dead, decaying algal material, especially Ascophyllum nodosum thalli, found on the shore at high tide mark or above. The algal material that supports the fruiting of $C$. marina is in the early to middle stages of the decay process. It seems that the fungus fruits rather quickly after the algae are washed ashore which indicates a colonization from marine sources, suggesting that the fungus is already present as an endophyte in or on the algae when the material is washed ashore.

There are presently 41 records listed for Scotland and England in the checklist of fungi of the British Isles (http://www.fieldmycology.net/FRDBI/FRDBI.asp). The fungus is easily found in Troms $\emptyset$ in Northern Norway, and is presumably common in the temperate and arctic waters along the whole Western European coast up to the White Sea, where it is known to be common (Tchesunov et al. 2008). Twelve specimens from Scandinavia are preserved in UME and UPS, including three from brackish water of the Baltic Sea (Skåne and Gotland) with salinity of 7-7.5 (http://tangbloggen.com/2012/01/24/ostersjon/). It is unknown whether the fungus can exist and produce fruiting bodies on Fucus vesiculosus and the endemic F. radicans in the eastern and northern parts of the Baltic Sea with extremely low salinity (3-7).

Boyd found the fungus fruiting in April-May and August-September in Scotland (Smith 1909), and Eriksson (1973) in April, June and July in Scandinavia. We recorded fruiting bodies also in January, February, May and November, and there are specimens in K collected in December, and observations in the British database from October. Consequently, March is the only month in which fruiting bodies have yet to be collected. Based on this, we can confirm Boyd's assumption (in Smith 1909) of the year-round fruiting in suitable habitats.

Acknowledgments: Troms $\varnothing$ University Museum at the Arctic University of Norway and Geir H. Mathiassen provided financial support. We are grateful to E.B. Gareth Jones who kindly provided help during the fieldwork, to Ove E. Eriksson who commented an earlier version of this manuscript, and to Paul Kirk for his nomenclatural support. Guy Marson is thanked for gaining sequences of Corticifraga peltigerae, Calloria urticae and Laetinaevia carneoflavida. Ekaterina Bubnova gave us information about the distribution of Calycina marina in Northwest Russia, and Robert Barrett improved the English.

\section{References}

Baral, H.O. 1987. Lugol's solution/IKI versus Melzer's reagent: hemiamyloidity, a universal feature of the ascus wall. Mycotaxon 29: 399-450.

Baral, H.O. 2009. Iodine reaction in Ascomycetes: why is Lugol's solution superior to Melzer's reagent? http://www.invivoveritas.de. Accessed 20 October 2015.

Benson, D.A., K. Clark, I. Karsch-Mizrachi, D.J. Lipman, J. Ostell and E.W. Sayers. 2014. GenBank. Nucleic Acids Res. 42: D32-D37.

Darriba, D., G.L. Taboada, R. Doallo and D. Posada. 2012. jModelTest 2: more models, new heuristics and parallel computing. Nat. Methods 9: 772-772.

Eriksson, 0. 1973. Orbilia marina, an over-looked Discomycete on members of Fucales. Svensk Bot. Tidskr. 67: 208-210.

Gargas, A. and J.W. Taylor. 1992. Polymerase chain reaction (PCR) primers for amplifying and sequencing nuclear 18S rDNA from lichenized fungi. Mycologia 84: 589-592.

Guindon, S. and O. Gascuel. 2003. A simple, fast, and accurate algorithm to estimate large phylogenies by maximum likelihood. Syst Biol. 52: 696-704. 
Hein, B. 1976. Revision der Gattung Laetinaevia Nannf. (Ascomycetes) und Neuordnung der Naevioideae. Willdenowia. Beiheft 9: 3-136.

Jaklitsch, W., H.O. Baral, R. Lücking and T. Lumbsch. 2015. Part 1/2 Ascomycota. In: (W. Frey, ed.) Syllabus of plant families. J. Cramer, Borntraeger, Stuttgart.

Johnson, D., G.-H. Sung, N.L. Hywel-Jones, J.J. Luangsa-Ard, J.F. Bischoff, R.M. Kepler and J.W. Spatafora. 2009. Systematics and evolution of the genus Torrubiella (Hypocreales, Ascomycota). Mycol. Res. 113: 279-289.

Jones, E.B.G., J. Sakayaroj, S. Suetrong, S. Somrithipol and K.-L. Pang. 2009. Classification of marine Ascomycota, anamorphic taxa and Basidiomycota. Fungal Divers. 35: 1-187.

Katoh, K. and D.M. Standley. 2013. MAFFT multiple sequence alignment software version 7: improvements in performance and usability. Mol. Biol. Evol. 30: 772-780.

Kirk, P. and B. Spooner. 1984. An account of the fungi of Arran, Gigha and Kintyre. Kew Bull. 38: 503-597.

Kohlmeyer, J. and E. Kohlmeyer. 1979. Marine Mycology: The Higher Fungi. Academic Press, New York, NY. pp. 690.

Matheny, P.B., Y.J. Liu, J.F. Ammirati and B.D. Hall. 2002. Using RPB1 sequences to improve phylogenetic inference among mushrooms (Inocybe, Agaricales). Am. J. Bot. 89: 688-698.

Murray, M.G. and W.F. Thompson. 1980. Rapid isolation of high molecular weight plant DNA. Nuc. Acids Res. 8: 4321-4325.

Mysterud, I., K. Høiland, G. Koller and Ø. Stensrud. 2007. Molecular characterization and evaluation of plant litter-associated fungi from the spring "grazing corridor" of a sheep herd vulnerable to alveld disease. Mycopathologia 164: 201-215.

Nannfeldt, J.A. 1932. Studien über die Morphologie und Systematik der nicht-lichenisierten inoperculaten Discomyceten. Nova acta Regiae societatis scientiarum Upsaliensis. Ser. 4.8 (2): 1-368.

Pang, K.-L., S.Y. Guo, S.A. Alias, J. Hafellner and E.B.G. Jones. 2014. A new species of marine Dactylospora and its phylogenetic affinities within the Eurotiomycetes, Ascomycota. Bot. Mar. 57: 315-321.

Rambaut, A., M. A. Suchard, D. Xie and A. Drummond. 2014. Tracer v1.6, Available from http://beast.bio.ed.ac.uk/Tracer. Accessed 20 October 2015.

Rehner, S.A. and G.J. Samuels. 1994. Taxonomy and phylogeny of Gliocladium analysed from nuclear large subunit ribosomal DNA sequences. Mycol. Res. 98: 625-634.

Ronquist, F., M. Teslenko, P. van der Mark, D.L. Ayres, A. Darling, S. Höhna, B. Larget, L. Liu, M.A. Suchard and J.P. Huelsenbeck. 2012. MrBayes 3.2: Efficient Bayesian Phylogenetic Inference and Model Choice Across a Large Model Space. Syst. Biol. 61: 539-542.

Schoch, C.L., K.A. Seifert, S. Huhndorf, V. Robert, J.L. Spouge, C.A. Levesque, W. Chen and Fungal Barcode Consortium. 2012. Nuclear ribosomal internal transcribed spacer (ITS) region as a universal DNA barcode marker for Fungi. Proc. Natl. Acad. Sci. USA. 109: 6241-6246.

Smith, A.L. 1909. New or rare microfungi. Trans. Br. Mycol Soc. 3: 111-124, pl. 6.

Stiller, J.W. and B.D. Hall. 1997. The origin of red algae: Implications for plastid evolution. Proc. Natl. Acad. Sci. USA. 94: 4520-4525.

Suetrong, S. and E.B.G. Jones. 2006. Marine discomycetes: A review. Indian J. Mar. Sci. 35: 291-296.
Tchesunov, A., N. Kaljakina and E. Bubnova. 2008. A Catalogue of Biota of the White Sea Biological Station of the Moscow State University (Katalog bioty Belomorskoy biologicheskoy stantsii MGU). KMK Scientific Press Ltd, Moscow. pp. 384.

Triebel, D. and H.O. Baral. 1996. Notes on the ascus types in Crocicreas (Leotiales, Ascomycetes) with a characterization of selected taxa. Sendtnera 3: 199-218.

Vilgalys, R. and M. Hester. 1990. Rapid genetic identification and mapping of enzymatically amplified ribosomal DNA from several Cryptococcus species. J. Bacteriol. 172: 4238-4246.

White, T.J., T. Bruns, S. Lee and J. Taylor. 1990. Amplification and direct sequencing of fungal ribosomal RNA genes for phylogenetics. In: (M.A. Innis, D.H. Gelfand, J.J. Sninsky and T. J. White, eds) PCR Protocols: a guide to methods and applications. Academic Press, San Diego, CA. pp. 315-322.

\section{Bionotes}

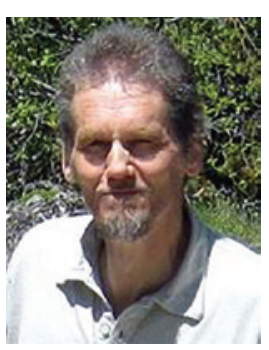

Hans-Otto Baral

Blaihofstraße 42, 72074 Tübingen, Germany

Hans-Otto Baral studied Biology at the University of Tübingen, Germany. Since the 1970s he has been working on the taxonomy, pleomorphy, phylogeny, and ecology of ascomycetes, particularly inoperculate discomycetes. Over 25 years ago, he started to work on a world-wide monograph of Orbiliomycetes which is presently being finished. During the past 30 years, he has published studies in various genera of Helotiales, including the cause of the ash dieback disease. His main concern is the study of living fungal cells, called "vital taxonomy", which he found to supply a much more reliable basis for morphology-based fungal taxonomy, and a better understanding of the function of fungal microstructures.

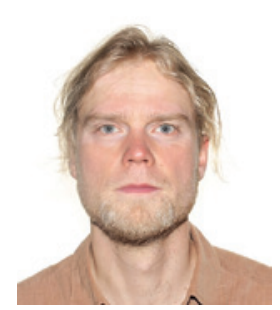

\section{Teppo Rämä}

Norwegian College of Fishery Science, UiT - The Arctic University of Norway, Postbox 6050 Langnes, Tromsø, NO-9037, Norway teppo.rama@uit.no

Teppo Rämä is mycologist and postdoctoral fellow in Marine Biodiscovery. His work with fungi started in Finland in the 2000s, and in 2014 he received his PhD at the University of Troms $\varnothing-$ The Arctic University of Norway. He is interested in the diversity and biology of fungi, and especially the species that are found in the marine environment. His current research focuses on marine fungal biodiscovery and biosystematics. 